\section{Use of Geotextile Disks for Container Weed Control}

\author{
Bonnie L. Appleton ${ }^{1}$ and Jeffrey F. Derr ${ }^{2}$ \\ Hampton Roads Agricultural Experiment Station, Virginia Polytechnic \\ Institute and State University, Virginia Beach, VA 23455
}

Additional index words. Pinus strobiformis, Southwestern white pine, Pistacia chinensis, Chinese pistache, Rhododendron indicum $\times$ 'Fashion', 'Fashion' azalea, landscape fabrics, weed barriers, oxyfluorfen, pendimethalin, oxadiazon, oryzalin, benefin

\begin{abstract}
Disks of several geotextiles, paper, fiberglass, and black polyethylene were compared with the herbicides oxyfluorfen plus pendimethalin, oxadiazon, and oryzalin plus benefin for suppression of weed growth around container-grown Southwestern white pine (Pinus strobiformis Engelm.), Chinese pistache (Pistacia chinensis Bunge.), and 'Fashion' azalea [Rhododendron indicum (L.) Sweet $\times$ 'Fashion']. The greatest weed control was obtained with a combination geotextile-preemergence herbicide (trifluralin) disk, indicating a possible new method of container weed control. Several of the barrier materials, including heavy wrapping and compressed peatmoss papers, black polyethylene, and one spunbonded geotextile, were inferior due to degradation or to weeds growing around the disk edges or center hole. No difference in crop growth was noted among the treatments. Chemical names used: 2-chloro-1- (3-ethoxy-4-nitrophenoxy)-4-(trifluoromethyl) benzene (oxyfluorfen); N-(1-ethylpropyl)-3,4 -dimethyl-2,6-dinitrobenzenamine (pendimethalin); 3-[2,4-dichloro-5 -(1-methylethoxy)phenyl]-5-(1,1dimethylethyl)-1,3,4-oxadiazol-2-(3H)-one (oxadiazon); 4-(dipropylamino) -3,5 -dinitrobenzenesulfonamide (oryzalin); N-butyl-N-ethyl-2,6 -dinitro-4-(trifluoromethyl) benzenamine (benefin); 2,6-dinitro-N,N-dipropyl-4-(ttifluoromethyl)benzenamine (trifluralin).
\end{abstract}

A major problem with container production of nursery stock is weed control. Weeds detract from the appearance of the plants at sale time and reduce both crop size and quality (Fretz, 1972; Walker and Williams, 1985).

Weed seed is introduced into production via wind, irrigation, or medium or liner contamination. The major weed control measures for container production are the use of herbicides and hand weeding. While cultivation is an additional weed control measure in field nursery production and landscape maintenance, it is not feasible in container production.

Although an adequate number of effective preemergence herbicides exist, some growers are hesitant to use herbicides due to the potential for damage, the limited number of species labeled, the timing required, or attempts to reduce chemical use. In addition, as more container growers recycle irrigation water, contamination of both recycled water and ground water is forcing growers to consider alternative weed control measures.

One alternative application method for container production is slow-release herbicide tablets (Gorski et al., 1989; Smith and Treaster, 1987; Verma and Smith, 1981). In

Received for publication 27 July 1989. Use of trade names in this publication is solely for identification. No endorsement of the products named is implied by VPI \& SU. The cost of publishing this paper was defrayed in part by the payment of page charges. Under postal regulations, this paper therefore must be hereby marked advertisement solely to indicate this fact.

'Dept. of Horticulture.

'Dept. of Plant Pathology, Physiology, and Weed Science. for Chinese pistache.) $)^{2}$ generally better if the geotextiles were left unmulched. Danielson (1967) reported that an herbicide-impregnated cellulose acetate cloth was generally as effective as spray applications in field trials.

Taylor (1963), using herbicide-impregnated burlap disks for container weed control, reported "good weed control with most herbicides, but had some test crop injury. Brown (1985) reported good weed control without crop quality reduction in containers with a felt funnel-shaped barrier and black or white polyethylene disks. The major disadvantage cited was the time required to wire the polyethylene film over the container rims. Wells et al. (1987) reported satisfactory weed control using black roofing felt, polyethylene (no color given), and woven geotextile "liners or covers" in containers if the materials remained in place. Geotextiles have the major advantages of permitting water penetration and allowing fertilizer application on top of their surface, thus not requiring their removal. In Canada, where before 1987 no herbicides were registered for container-grown nursery stock, Chong (1987) reported testing several "surface covers" (composition not specified) as alternatives to chemical weed control with good results.

Our preliminary studies were conducted to screen the weed-control capability in containers of certain geotextiles marketed for landscape weed control and to compare the effectiveness of these geotextiles with conventional preemergence nursery herbicides. Included in the study was a new geotextilepreemergence herbicide combination product $\{$ Biobarrier [Typar geotextile; Reemay, Old Hickory, Term., plus trifluralin (Treflan); Elanco Products, Indianapolis]\} being advertised for rerouting tree roots in landscape situations.

In addition, altering the color of the geotextiles was investigated due to reports of enhanced growth with certain vegetables and fruits using colored mulches. Decoteau et al.

Table 1. Growth of weeds seeded atop weed-control barriers. (Prostrate spurge for azaleas, crabgrass

\begin{tabular}{lccc}
\hline \hline & \multicolumn{2}{c}{ Prostrate spurge } & $\begin{array}{c}\text { Large } \\
\text { crabgrass }\end{array}$ \\
\cline { 2 - 3 } \multicolumn{1}{c}{ Treatments } & $\begin{array}{c}\text { Plants } \\
(\text { no./pot) }\end{array}$ & $\begin{array}{c}\text { Shoot fresh wt } \\
(\mathrm{g} / \mathrm{pot})\end{array}$ & $\begin{array}{c}\text { shoot fresh wt } \\
\text { (g/pot) }\end{array}$ \\
\hline No weed check & 3.8 & 1.82 & 19.9 \\
Weedy check & 160 & 30.1 & 179 \\
Oxy + pend $^{\mathrm{y}}$ & 25 & 6.20 & 91.1 \\
White sb & 29 & 10.6 & 82.3 \\
Yellow sb & 18 & 11.3 & 76.5 \\
Red sb & 7.0 & 6.98 & 67.2 \\
Blue sb & 9.0 & 12.5 & 69.9 \\
Black sb & 6.8 & 14.3 & 83.1 \\
Gray sb & 79 & 24.1 & 75.7 \\
Black woven & 5.5 & 10.8 & 74.1 \\
White woven & 12 & 13.2 & 73.6 \\
Fiberglass & 8.8 & 17.9 & 59.9 \\
Paper & 62 & 26.5 & 126 \\
Geo-herb & 0.0 & 0.00 & 0.00 \\
LSD $(0.10)$ & 30.6 & 10.7 & 30.3 \\
\hline
\end{tabular}

${ }^{2}$ Means of four single container replications. Mean separation in columns bySD, $P=0.10$.

$\mathrm{Oxy}+$ penal $=$ oxyfluorfen plus pendimethalin $(\mathrm{OH} 2)$.

${ }^{x} \mathrm{Sb}=$ spunbonded.

"Gee-herb = geotextile-preemergence herbicide combination product. 


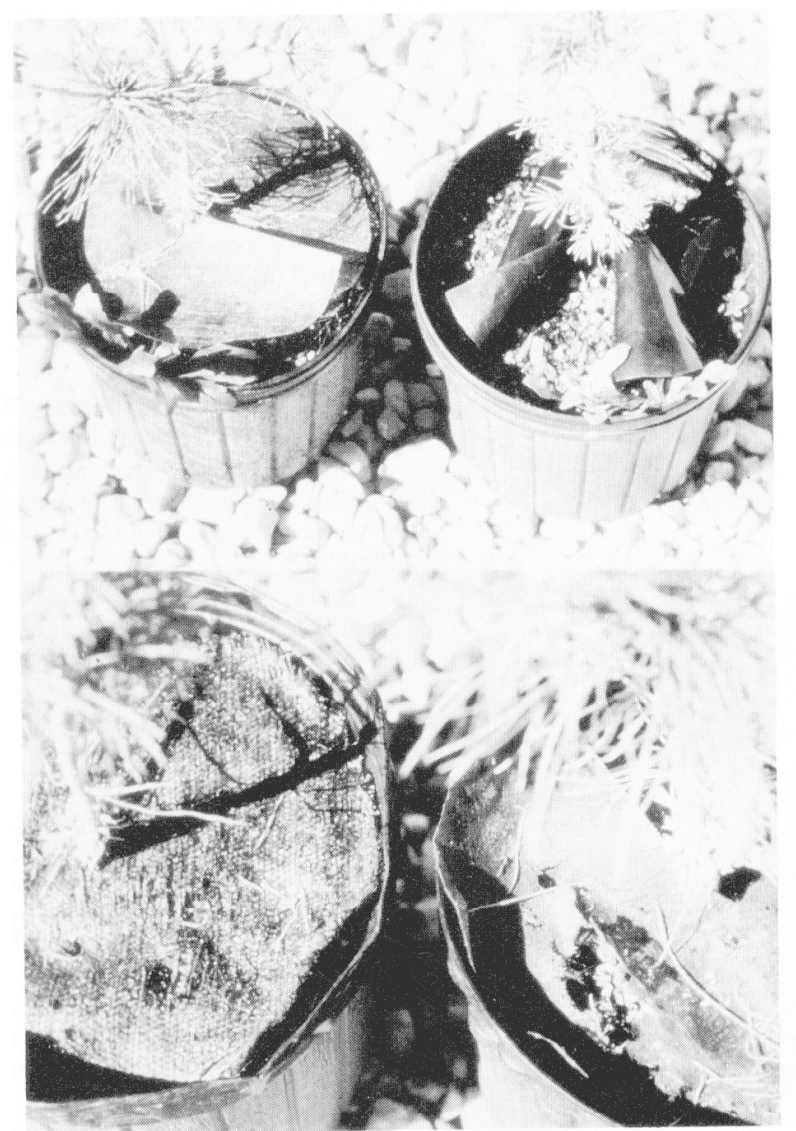

Fig. 1. Problems with weed control barriers-a light-weight geotextile being pushed up by weed growth (left top) and black plastic rolling up (right top); decomposition of geotextiles lacking ultraviolet light-inhibitors (bottom).

(1988, 1989) and Loy and Wells (1988) reported that colored mulches increased tomato growth and yield. Oh et al. (1986) reported increasing the growth and production of grapes with silver polyethylene mulch. Moreshet et al. (1975) increased the growth and production of apples with laminated plastic film vacuum-coated with aluminum.

In the first study, 2-year-old, untransplanted Southwestern white pine (Pinus strobiformis) seedlings were potted in 4-liter plastic containers in a medium of 3 ground pine bark : 1 sphagnum peatmoss : 1 sand (by volume) and topdressed with a $17 \mathrm{~N}-2.6 \mathrm{P}-$ 9.9K plus micronutrient slow release fertilizer (Sierra Controlled Release Fertilizer, Sierra Chemical, Milpitas, Calif.) at $9 \mathrm{~g} /$ container. The weed control treatments consisted of the two herbicides oxadiazon (Ronstar, Rhone-Poulenc Agricultural, Research Triangle Park, N. C.) and oryzalin plus benefin (XL, Elanco), paper disks consisting of two layers of heavy brown wrapping paper, 6-mil (6-mm) black polyethylene disks, and disks, cut from one of three geotextiles: a gray spunbonded (Typar, Reemay), a "fuzzy" black woven (DeWitt; DeWitt, Sikeston, $\mathrm{Me}$.), and a slick black woven type (Geoscape, Innovative Geotextiles, Charlotte, N.C.). All disks were cut slightly larger than the container diameter to fit snuggly in place, avoiding tedious wiring.

The seven treatments plus a control were replicated five times (single container) in a completely randomized block design on a sloped, black polyethylene-covered nursery bed with overhead irrigation. No weed seed was introduced, so all weeds that grew resulted from contamination sources.

In the second study, 12-cm-tail 'Fashion' azalea rooted liners and $15-\mathrm{cm}$-tall Chinese pistache seedlings were potted into 4-liter plastic containers in the same medium as above and topdressed with the same fertilizer at $3 \mathrm{~g} /$ azalea and $9 \mathrm{~g} /$ Chinese pistache. Weed control treatments consisted of one herbicide combination product; oxyfluorfen plus pendimethalin (OH2, O.M. Scott and Sons, Marysville, Ohio); one paper disk (Hortopaper, Actagro, Fresno, Calif.); one fiberglass disk (Figer-Mulch, Buckley Industries, Wichita, Kan.); eight geotextile disks (a white spunbonded) (Exxon, Landscape Supply, Roanoke, Vs.); the above-noted white spunbonded sprayed with yellow, red, blue, and black enamel paint; a white woven (DuPont, TEI, Baltimore); a gray spunbonded (Duon, Blunks Wholesale Supply, Bridgeview, Ill.); and a black woven type (DeWitt); and disks from the Biobarrier geotextile-preemergence herbicide combination product.

Pots containing the Chinese pistache were seeded with large crabgrass [Digitaria sanguinalis (L.) Scop], and the azalea with prostrate spurge (Euphorbia supina Raf.) (on top of the barriers), and were compared with no weed and weedy controls. The 12 treatments plus two controls were replicated four times (single container) in a completely randomized block design on a sloped, black polyethylene-covered nursery bed with overhead irrigation.

After 21 weeks in the first study, the treatments were visually evaluated on a rating scale, where" $1=$ no weeds, $2=1$ to 2 weeds, and $3=3$ or more weeds per container. Fewer weeds were observed with oryzalin plus benefin and the gray spunbonded and slick black woven disks (all 1.4) than in the control (2.1). No significant differences $(P=0.10)$ were observed with the other four treatments (paper, 2.0; oxadiazon, black polyethylene, and fuzzy black woven disks, 1.7). Weed growth had begun under the paper disks due to disk decomposition and around the outside edge of the black polyethylene disk because the polyethylene had begun to roll up (Fig. 1). All geotextiles were beginning to photodecompose due to a lack of ultraviolet light inhibitors, allowing weed growth (Fig. 1).

No significant growth differences were noted with the pines, presumably because what weed growth existed at the study's termination was relatively small.

After 20 weeks in the second study, the greatest overall control of both prostrate spurge and large crabgrass was obtained with the geotextile-preemergence herbicide disk (Table 1 and Fig. 2). Significantly more prostrate spurge plants grew in the paper (39\% of weedy check) and the gray spunbonded disk $(49 \%)$ treatments than in the combination disk $(0 \%)$, the no weed check $(2 \%)$, the herbicide treatment $(16 \%)$, and the remaining geotextile disks ( $3 \%$ to $18 \%$ ) (Table 1). Prostrate spurge fresh shoot weights were significantly lower for the combination disk ( $0 \%$ of weedy check), no weed check $(6 \%)$, herbicide treatment $(21 \%)$, and red spunbonded (23\%) disks than for the fiberglass (59\% of weedy check), gray spunbonded $(80 \%)$, and paper $(88 \%)$ disks (Table 1$)$. All other disks were intermediate.

Even greater differences developed with the more aggressive large crabgrass. Large crabgrass fresh shoot weights were significantly lower for the combination disk $(0 \%$ of weedy check) and the no weed check (11\%) than for all other treatments $(34 \%$ to $71 \%$ of weedy check) (Table 1).

Much of the failure of the geotextiles to adequately control weeds was lack of fit of the disks. Many weeds grew around the outside edges and through the hole cut in the center to fit around the liner or seedling. In addition, when light was transmitted through the geotextile due to color (white spunbonded) or when decomposition of the geotextile had begun (gray spunbonded), more weeds grew. Geotextile success as a weed barrier depends on fabric opaqueness, decomposition resistance, and a very tight fit around the container edge and liner.

No significant growth differences occurred with Chinese pistache or azaleas relative to barrier type or color (data not 


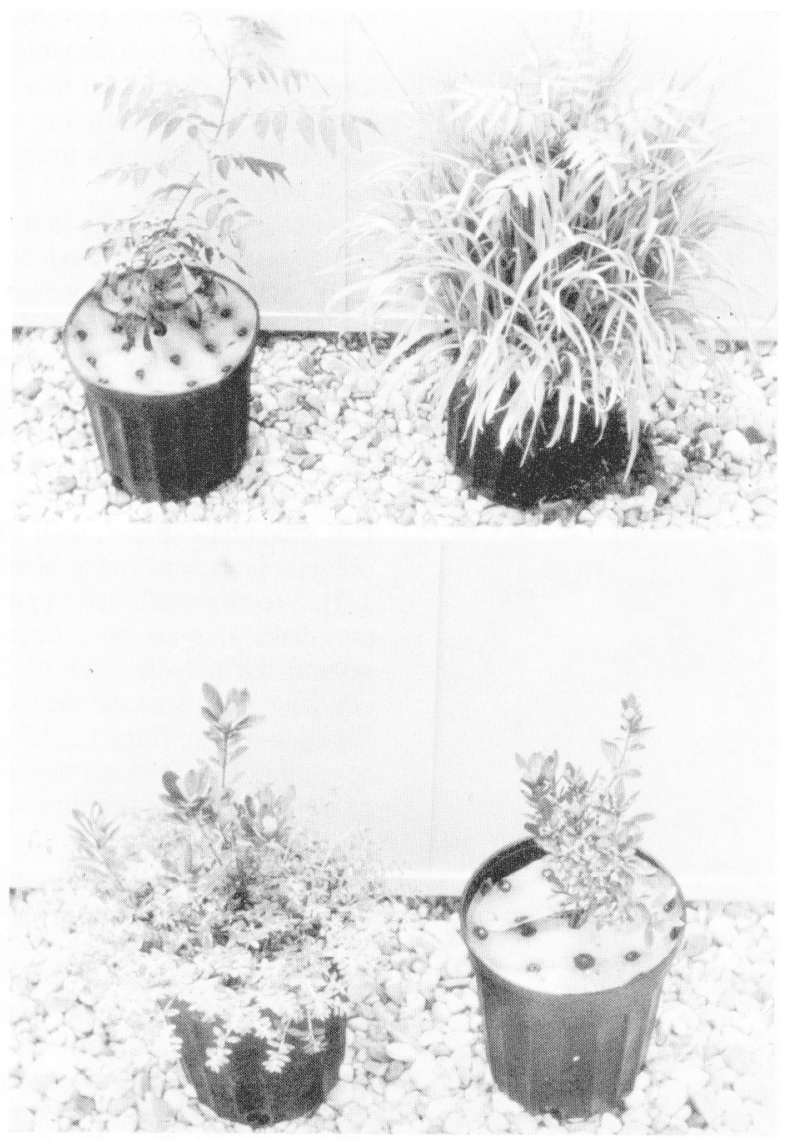

Fig. 2. Weedy check and geotextile-preemergence herbicide disk seeded with large crabgras(top) and prostrate spurge (bottom). Small dark spots on geotextile represent herbicide attachment points.

presented). We assume that the adequate levels of medium moisture and fertilizer that were maintained prevented crop growth reduction during the study, a result that would be expected to change during a typically longer production cycle.

Nonsignificant differences in weed control between the herbicide and most of the geotextiles alone (without preemergence herbicides) showed that use of the geotextiles for container weed control is not warranted. The geotextile-preemergence herbicide combi- impregnated cloth. Weeds 15:60-62.

Decoteau, D. R., M.J. Kasperbauer, D.D. Daniels, and P.G. Hunt. 1988. Plastic mulch color effects on reflected light and tomato plant growth. Sci. Hort. 34:169-175

Decoteau, D. R., M.J. Kasperbauer, and P.G. Hunt. 1989. Mulch surface color affects yield of freshmarket tomatoes. J. Amer. Soc. Hort. Sci. 114:216-219.

Derr, J.F. and B.L. Appleton. 1989. Weed control with landscape fabrics. J. Environ. Hort. 7:129-133.

Fretz, T.A. 1972. Weed competition in container grown Japanese holly. HortScience 7:485-486.

Gorski, S. F., S. Reiners, and M.A. Ruizzo. 1989. Release rate of three herbicides from controlledrelease tablets. Weed Technol. 3:349-352.

Loy, J.B. and O.S. Wells. 1988. Wavelength selective plastic mulches for vegetables. ASHS/ CSHS 1988 Annu. Mtg., East Lansing, Mich. Prog. \& Abstr. HortScience 23(3):763[107].

Moreshet, S., G. Stanhill, and M. Fuchs. 1975. Aluminum mulch increases quality and yield of 'Orleans' apples. HortScience 10:390-391.

Oh, J. Y., J.K. Byun, S.B. Lee, and D.U. Choi. 1986. The effects of cane bagging with polyethylene film, reflective (silver) and transparent film mulch on vine growth and berry ripening of 'Campbell Early' (Vitus labruscana B.) grape. J. Kor. Soc. Hort. Sci. 27:127-135.

Smith, E.M. and S.A. Treaster. 1987. An evaluation of cyanazine, terbacil and metolachlor slow-release herbicide tablets on woody landscape crops. Ohio Agr. Res. and Dev. Ctr. Res. Circ. 289. p. 15-16.

Taylor, J.L. 1963. Herbicide treated burlap as a method of applying preemergence herbicides to container grown nursery plants. Proc. Southern Weed Conf. 16:143-144.

Verma, B.P. and A.E. Smith. 1981. Dry-pressed slow release herbicide tablets. Trans. Amer. Sot. Agr. Eng. 24:1400-1403, 1407.

Walker, K.L. and D.J. Williams. 1985. Weed interference by three grass species in container grown nursery crops. Proc. North Central Weed Control Conf. 40:96.

Wells, D.W. and R.J. Constantin. 1986. Herbicide-treated pine bark mulch for container-grown ornamental. HortScience 21:934. (Abstr.)

Wells, D. W., R.J. Constantin, and W.L. Brown. 1987. Weed control innovations for large, container-grown ornamentals. Proc. Southern Weed Sci. Soc. 40:137. 